\title{
Academic integrity policies of Baltic state- financed universities in online public spaces
}

\author{
Alla Anohina-Naumeca ${ }^{1}$, Loreta Tauginiene $\dot{2}^{2^{*}}$ (D) and Tatjana Odineca ${ }^{3}$
}

\author{
* Correspondence: loreta. \\ tauginiene@knf.vu.lt \\ ${ }^{2}$ Vilnius University, Muitinès g. 8, \\ LT-44280 Kaunas, Lithuania \\ Full list of author information is \\ available at the end of the article
}

\begin{abstract}
Academic integrity determines the trust that society has in the quality of education and the results of scientific research. More broadly, it influences honesty, respect for ethical principles, and the fair behaviour of society members. Accordingly, higher education institutions should have clear, transparent and well-communicated policies to defend academic integrity among all stakeholders. Taking into account the worldwide dependence on digital technologies, online communication channels should be also used for this purpose. Using qualitative content analysis, this paper aims to investigate how academic integrity is framed by Latvian and Lithuanian state-financed universities in online public spaces in relation to the criteria of an exemplary academic integrity policy. Given the limited content of publicly available university documents, the research findings indicated a poor correspondence to the mentioned criteria.
\end{abstract}

Keywords: Academic integrity, Policy, Higher education, Online public spaces

\section{Introduction}

The reiteration of the discussion on ethical issues in academia implies that academic integrity is impervious to time, so it does not lose its relevance. Academic integrity refers to "compliance with ethical and professional principles, standards and practices by individuals or institutions in education, research and scholarship" (Tauginienè et al, 2018: 7-8). It transcends all kinds of activities carried out at and by a university that may become sensitive due to ethical concerns and related conflicts.

The need to identify ethical issues in academia requires being in regular search of efficient solutions of how to prevent malpractices and intervene when they appear. The search for such solutions is normal practice; a systematic approach of shaping, implementing, auditing, revisiting, and further developing institutional values and related norms comprises the essential stages of ethics management (Kaptein 1998; Pučètaitè and Lämsa 2008; Vasiljevienè 2006; Wieland 2003). In spite of these developmental stages, ethics management does not always take the same transition pathway in all regions, particularly in estimating the level to which ethics infrastructure (or ethics management tools) is developed. Ethics infrastructure covers various means, such as ethics training, ethics committees, codes of ethics, helplines, and ombudsman or compliance services, ethics audit and so forth (Driscoll and Hoffman 1999; Francis and Armstrong 2003; Tauginienė 2016; Vasiljevienė 2006; Vasiljevienė and Jakimenko 2012).

(c) The Author(s). 2018 Open Access This article is distributed under the terms of the Creative Commons Attribution 4.0 International License (http://creativecommons.org/licenses/by/4.0/), which permits unrestricted use, distribution, and reproduction in any medium, provided you give appropriate credit to the original author(s) and the source, provide a link to the Creative Commons license, and indicate if changes were made. 
These means serve to embed institutional values that consequently assist in promoting ethical behaviour. However, each organisation determines which of the means should come first; therefore, the development of ethics infrastructure and ethics management may also be uneven.

In Baltic countries such as Latvia and Lithuania, accomplishment of academic integrity policy differs. As evidence of this, in Lithuania academic integrity is described in numerous university documents; therefore, it is dispersed into a few area-specific regulations, codes of ethics, and other university core documents (such as strategy and strategic plan) (e.g. Tauginienè 2015, 2016). Meanwhile, in Latvia, aspects and concerns of academic integrity in public communication are generally disregarded, and clear terminology (even, for example, the definition of plagiarism) has not been developed (Upleja 2012). A number of academic integrity issues in both Latvian and Lithuanian universities are also described in reports developed under the Impact of Policies for Plagiarism in Higher Education across Europe (IPPHEAE) project (Stabingis 2013, 2014).

Furthermore, the publication of university policies linked to some extent with academic integrity is an important means of substantiating university social responsibility. In principle, such policies are part of the set of core university policies and determine the identity role of universities (Albert and Whetten 1985; Winter and O'Donohue 2012). Hence, the way universities make decisions mirrors whether and to what extent in reality they follow the policies. These policies usually define what is acceptable and unacceptable and describe responsible bodies, procedures, and sanctions. Such a policy structure implies a university's concern for academic integrity; therefore, university assumes its responsibility through the need to comprehensively internalize academic integrity. This facilitates gaining societal trust and increasing university performance credibility towards university-related stakeholders. In addition to this, responding properly and promptly to malpractices shows a university's ability to deal with them. When malpractices are escalated in online public spaces, such as the media, it implies that ethics infrastructure operates rather formally. As a result, a university's reputation, the professionalism of its staff (e.g., Bridges 1998; Leja 2010) and alumni (e.g., Bieliauskaitè 2014), and trustworthiness in its activities might be questionable. It would definitely also translate into doubt about both university social responsibility and the ethics management that should enable it. Another aspect of having publicly available university policies related to academic integrity is a way of showing accountability towards the expectations of society as taxpayers. Society expects that any employer should be able to rely on education as credible and uncompromised through receiving professional services or products (e.g. Bieliauskaite 2014).

Another significant factor is the dependence of modern society on technology: students entering universities in the last few years are considered to be a digital generation (Echenique 2014; Jones and Shao 2011) with extensive use of mobile internet for accessing social network portals, multimedia content, entertainment sites, news portals, and websites of interest. In this context, digital technologies, and especially online communication channels, should be also used for communicating and defending academic integrity among students, teachers and researchers, and the general public. IPPHEAE reports also suggest that Latvian and Lithuanian universities should improve the public availability of policies and procedures for plagiarism prevention and punishment, as well as for intellectual property preservation (Stabingis 2013, 2014). 
Given the scale of issues interconnected to articulating academic integrity publicly and institutionally, this paper aims to examine how academic integrity is framed by Latvian and Lithuanian state-financed universities in online public spaces. In line with this aim, the research question is how academic integrity policy in Latvian and Lithuanian state-financed universities satisfies the components of an exemplary academic integrity policy. To do this, qualitative content analysis was conducted of publicly available university documents and relevant press articles of the selected universities.

The next section of this paper provides a literature review on academic integrity policy, followed by the methodological approach and findings. The paper ends with conclusions.

\section{Academic integrity policy}

The way a university substantiates academic integrity in its policy statements will predetermine its potential effect, but its actual effectiveness will only be achieved if the university coherently interconnects its policies and procedures with its practice (Bretag et al. 2011). Such a policy is not itself sufficient to establish academic integrity, as this requires a long-term and colossal effort that should be followed with additional prevention-and-intervention-driven activities (e.g., training, establishing related procedures) and aligned with university core activities, such as teaching and learning practices, scientific activity and others. Academic integrity policy seems effective when it is a formal process rather than a case-by-case method (Winters Spain and Robles 2011) and coherent with the variety of initiatives that are undertaken in a university, without any leeway (Kolb et al. 2015). In addition to this, it is implied that academic integrity policy would be more effective if developed by those to whom it is supposed to be applied, so it would be better accepted and respected (Löfström 2016; Richards et al. 2016).

In line with academic integrity policy effectiveness, some components need to be identified whereby academic integrity policy could serve as an example to achieve this. Bretag et al. (2011) distilled five components of exemplary academic integrity policy access, approach, responsibility, detail, and support. No priority is given to any of these components, i.e. all components are interrelated. Access refers to simple and easy availability of academic integrity policy for any stakeholder in terms of acquiring and understanding it. Approach evidences a "systematic and sustained commitment to the values of academic integrity and the practices that ensure it" (Bretag et al. 2011, p. 9). Responsibility relates to the scale of relevant stakeholders to whom responsibility is addressed, including all kinds of levels (such as individual, organisational, education system, and social). Detail unfolds what level of detail was given to describe ethical infringements when classifying them, and explaining levels of severity. Support testifies what other activities are envisaged to embed academic integrity, i.e. other ethics management tools.

\section{Methodological approach}

\section{Sample}

In this paper we focus on Latvian and Lithuanian public universities that are the largest by the number of enrolled students and, therefore, supposedly have the greater impact on society. According to statistics of 2017, Latvia has 16 state-financed and 11 private 
universities (Izglītibas un zinātnes ministrija 2017). However, only four of all public universities could be considered the largest ones as they cover $73 \%$ of the student population funded from the state budget. In 2016, 14 public and 7 private universities operated in Lithuania (Lietuvos statistikos departamentas 2017). Three major Lithuanian public universities cover $48 \%$ of the student population in public higher education. These Baltic universities carry out activities in all scientific fields, ranging from social sciences and humanities to biomedical, physical, and technological sciences.

\section{Data collection}

Documents are generally useful in understanding a current situation (Grady 1998). According to Hancock et al. (2009) they help to "understand the philosophy of an organization" (p. 19). Atkinson and Coffey (2011) note that in the context of the pervasive significance of documentary records (including electronic and digital resources) in the contemporary world, documentary realities should be studied in a careful way because they allow understanding how organizations work, justify themselves to relevant stakeholders, and publicize themselves.

To acquire evidence on academic integrity policy, we looked for two types of publicly available documents (so-called public records): a) academic integrity policies and other related regulations available on the websites of the selected public universities; and b) press articles related to academic integrity or other ethical issues in the selected public universities on the most popular Latvian and Lithuanian news portals. The second set of documents - press articles - supplement university policies in the way that universities explain these policies publicly, either on their own initiative or at the request of a journalist. This helps to comprehend the university philosophy regarding academic integrity in a more thorough way and provides real-life interpretations of the policies. Moreover, each press article reflects different voices as the journalist interviews all stakeholders that agree to discuss a particular case publicly. Press articles usually contain quoted excerpts from interviews with stakeholders.

The acquisition and processing of documents from the university websites proceeded in two steps: 1) searching documents on academic integrity using a site map and navigating available menus; and 2) searching additional documents by entering diverse keywords (e.g. ethics, academic integrity/honesty, plagiarism in Latvian/Lithuanian language) in the search field. After completing these steps, no academic integrity policy was detected as a single and separate document in any selected universities; however, mentions on academic integrity occurred in specific regulations. In general, the corpus of the identified documents included 41 documents in Latvia and 84 documents in Lithuania which mention academic integrity to some extent. These documents serve different purposes, e.g., university statutes, codes of ethics, and diverse education, research and scholarship-related regulations, such as related to organisation of studies, doctoral studies in a certain field of research, paper writing, traineeship, evaluation of achievements, and so forth.

To investigate how news portals frame academic integrity to lay people, we used Gemius internet research data on the most visited online news portals in Latvia and Lithuania (Gemius Baltic 2018; Gemius Latvia 2017) and entered the same keywords to search for press articles related to the selected public universities. Maintaining the same 
line of search helped us to consistently portray how universities delineate academic integrity in online public spaces and how this delineation shifts within the last 5 years (namely during the period of 2013-2017) while raising public awareness. As a result, we identified 33 press articles in total for both countries (Table 1).

\section{Data analysis}

Having collected all necessary documents, we proceeded to read them and highlight how the components of an exemplary academic integrity policy - access, approach, responsibility, detail, and support (Bretag et al. 2011) - are addressed. Hence, the research question is how academic integrity policy in Latvian and Lithuanian state-financed universities satisfies the components of an exemplary academic integrity policy. To answer this research question, we used the qualitative content analysis to examine university documents and press articles. The content analysis allowed us to study with what situational context academic integrity policy is associated (George, 2009). Situational contexts helped us to understand who interacts with whom, under what circumstances and to what extent.

\section{Findings}

The main set of collected data is presented in Table 2. Data analysis on academic integrity policy is profiled by country.

Latvia

Access

The websites of the three Latvian universities do not include a single (separate) section fully designated for documentary records on academic integrity (LV1, LV3, LV4), except for one university that has an integrated section titled "Academic ethics" on its website (LV2). However, it is difficult to find this section as it can only be reached after performing five clicks. Other universities have a main document on academic integrity - a code of ethics - located among other documents related to university performance, and usually this needs up to four clicks to open it.

\section{Approach}

Two universities additionally provide such a document as a code (rules) for academic integrity (LV2, LV4). While the code of ethics mainly defines university ethical values and principles of ethical behaviour with a sporadic mention of possible academic malpractice, the code of academic integrity lists different types of breaches for different stakeholders and describes punishment mechanisms.

Furthermore, educative and preventive mechanisms towards academic integrity used by the universities are publicly unreported. One of the universities declares that it provides an opportunity for students to check their work for plagiarism before final

Table 1 Number of press articles

\begin{tabular}{lllllll}
\hline & 2013 & 2014 & 2015 & 2016 & 2017 & Total \\
\hline Latvia & 0 & 4 & 5 & 1 & 1 & 11 \\
Lithuania & 2 & 2 & 1 & 1 & 16 & 22 \\
\hline
\end{tabular}




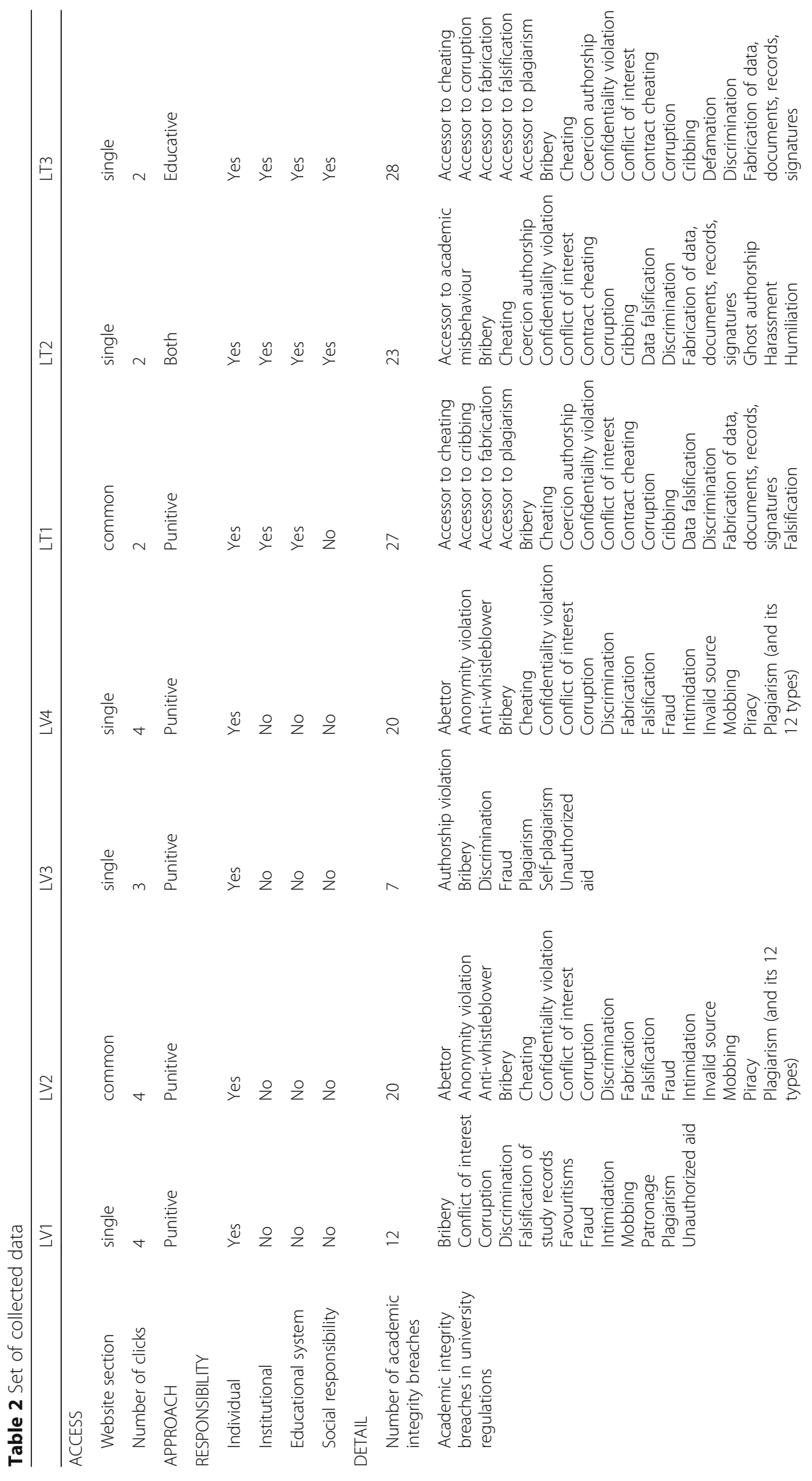




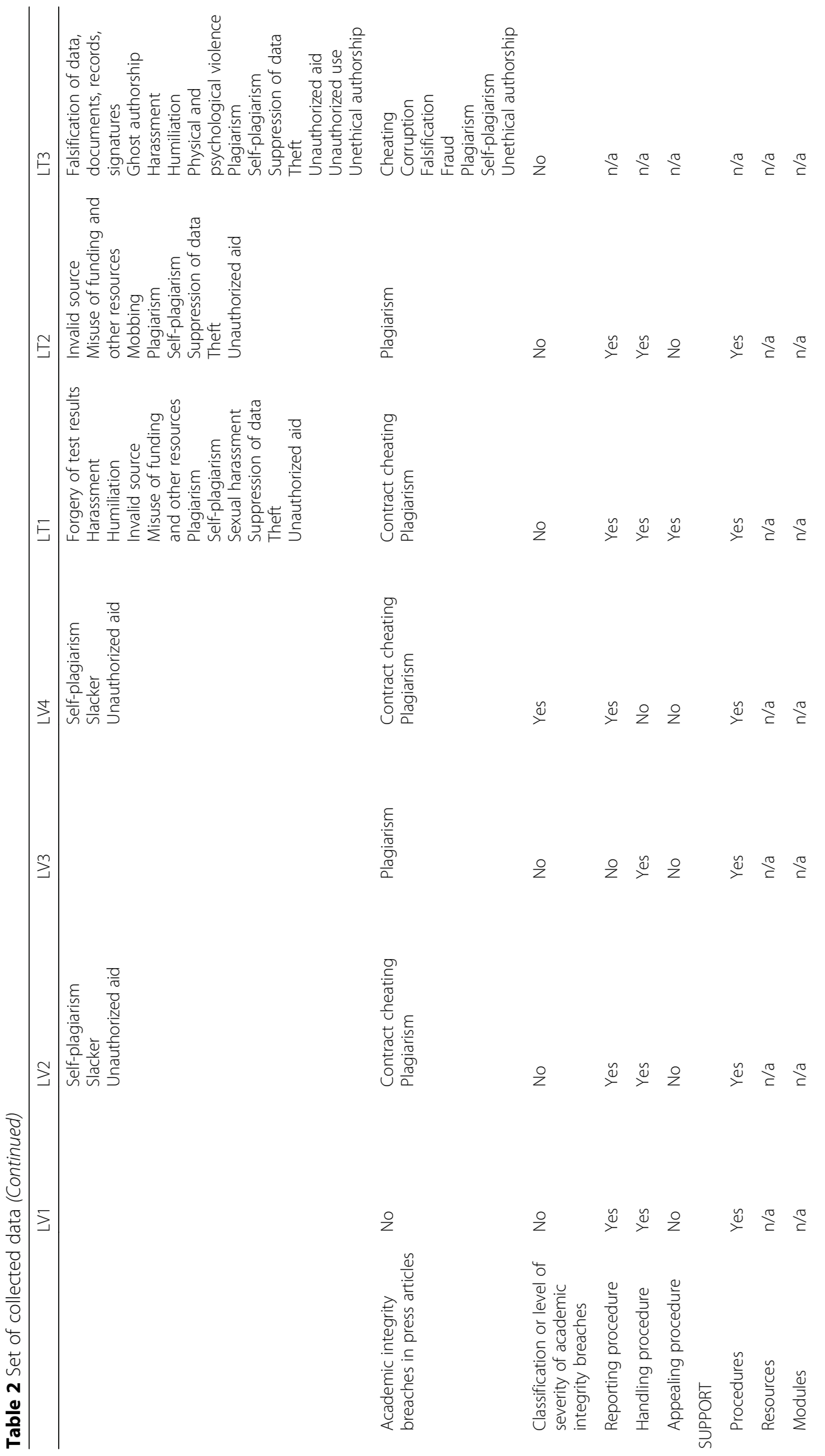




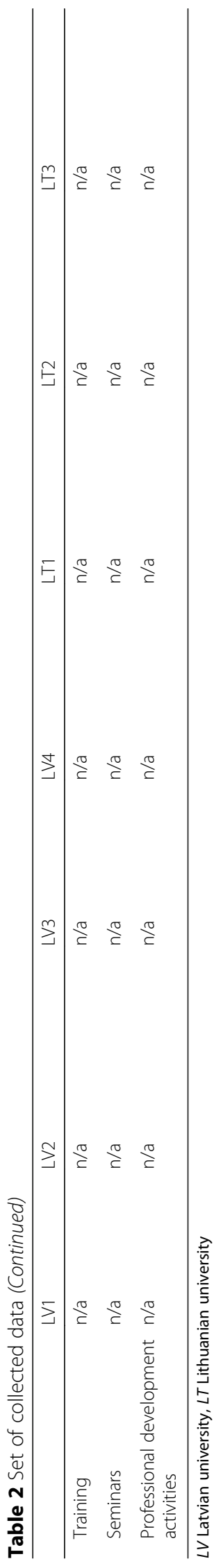


submission, but this is a chargeable service (LV1). Another university still keeps on its website several publications by university staff on academic integrity, especially related to fraud, plagiarism, and academic integrity, but they were last updated in 2009 (LV2). Although there are some provisions explaining forms of unethical behaviour and encouraging ethical behaviour, sanctions related to academic malpractices, especially from the students' side, are disproportionally greatly described. Hence, the predominance of sanctioning allows Latvian universities to be characterized as taking rather a punitive approach.

\section{Responsibility}

All four universities mainly address the individual responsibility of researchers, students, academics, and other professional staff. The evidence of responsibility at institutional, educational system and society levels is minimally presented in the documents and press articles.

\section{Detail}

The sets of academic integrity-related malpractices are quite different among the selected universities. Two universities communicate explicitly a detailed list of academic breaches linked to different stakeholders - students, scientific performance, and administration - in the code of academic integrity (LV2, LV4). While some of the breaches are common for all stakeholders (e.g. plagiarism and falsification), others are defined only for a particular audience (e.g. formal participation in group work for students). At the same time, some types of academic malpractices are not named clearly but they are delivered as a type of behavioural guidelines on what should not be done or followed. Both these universities mention detailed sanctioning mechanisms for student academic malpractice, while possible sanctions for academic and other university staff are redirected into a kind of disciplinary sanction. One of the universities provides a description of possible types of plagiarism and some specifications, such as amount of plagiarized text, or presence/absence of a student's previous dishonest practice that should be taken into account while evaluating a specific case of plagiarism (LV2). Another university defines four levels of severity of academic malpractices: bad academic practice, plagiarism, very serious plagiarism, and rigorous academic malpractice (LV4). Afterwards, the university focuses on different types of plagiarism, illustrates them with examples and aligns them with the four levels of severity and guidelines for applying sanctions in each case. In two other universities, information on academic malpractices is very scarce - academic breaches are not named properly and not arranged by the level of severity (LV1, LV3).

The universities have a different number of definitions of concepts related to academic integrity. In general, definitions of plagiarism, academic integrity, self-plagiarism, unauthorized aid, fabrication, and copying can be found in the documents. Two universities are consistent in their use of the definitions of the concepts (LV2, LV3) while the other two give different definitions of the same concept in different documents (LV1, LV4). For the latter universities, such a stance implies a poor vocabulary on academic integrity, hence the lack of an institutionalised understanding of academic integrity. 
Only one university provides very detailed information on reporting and handling procedures of academic malpractice (LV2). Two of the selected universities publicly present a complaint form about student malpractice (LV2, LV4). The reporting and handling procedures in other universities are described in a vague way, leaving out the description of many important aspects such as specific deadlines, requirements for an ethics commission (e.g. scale and ratio of representativeness) and roles of members (such as chair, vice-chair, secretary), etc. Appeal procedures in relation to academic malpractices are typically disregarded and, in the best case, there is a reference to the common university appeal procedure described in some other regulations.

Two of the four universities are most often mentioned in the press articles (LV2, LV3), while the other two are referred to extremely rarely (LV1, LV4). The most articles describe the universities using local text-matching software. In a few other press articles, various representatives of the universities (usually not administrative staff) mainly provide their own subjective judgments in relation to plagiarism and/or contract cheating without referring to the accepted policy on academic integrity of the university which might have been expected. However, only one university presents clearly in some press articles the university's position on alleged plagiarism in staff theses and contract cheating (LV2).

\section{Support}

A commission of ethics is established in all four universities, while two universities make publicly available regulations related to the commission's functioning (LV1, LV2) and one incorporates the its operational principles in the code of ethics (LV3). Furthermore, text-matching software is mentioned both in the publicly available documents and in the press articles. The universities use a common local automatic text-matching system shared by many Latvian universities. One university, over the last few years, additionally has used internationally recognized Turnitin software, and a very detailed instruction on its use is publicized (LV3).

Lithuania

Access

The selected university websites provide a separate section where all university main documents and further links to other area-specific sub-sections (e.g., research, for students) are provided. Usually, it needs up to two clicks to gain access either to a code of ethics or the information on ethics committee; however, up to four clicks are needed to find other regulations in which academic integrity and dishonesty are further mentioned.

\section{Approach}

Codes of ethics in the selected universities are of nearly identical content, but of different linguistic construction that, in turn, transforms the message on academic integrity rather into educative approach. For example, "the following behaviours contravene the principle of academic integrity: <...>" (LT3-D19); "From ethical perspective academic community members ought to $\langle\ldots\rangle$ actively follow standards of academic integrity $<\ldots>$ in the process of studies and research performance" (LT2-D15). 


\section{Responsibility}

University documents mostly address individual responsibility, while in press articles the sense of responsibility is raised to the level of universities as institutions responsible for the quality of higher education and research, as well as to the level of the education system and social responsibility. However, the latter level of responsibility is underdeveloped due to a lack of attention until lately, only since 2017: it is unclear whether the education system and social responsibility have the potential to be further sufficiently and properly addressed.

\section{Detail}

A code of ethics appears to be an essential document for shaping academic integrity policy. It delivers a wide spectrum of malpractices (see Table 2) whereas other university regulations mention very few of them again. The lists of academic integrity breaches coincide to a large extent. Furthermore, universities do not name all malpractices as concepts or terms, but rather mostly describe them by attributes or suggest a narrow definition of certain terms, such as plagiarism and authorship.

The diversification of academic integrity breaches is dissimilar in the selected universities. There are mentions that attention should be paid to the level of severity, or sanctions are imposed based on whether the academic integrity breach is committed for the first time or repeatedly. Nevertheless, doctoral regulations envisage more no-choice sanctions, such as expulsion due to unethical behaviour (LT1, LT3) and revocation of doctoral degree due to scientific misconduct (LT1-LT3).

Reporting and handling procedures are published online by two universities (LT2, LT3). It is clear to whom, what and how to report (e.g. requirements for the structure of a complaint); however, university handling procedures lack clarity. For example, provisions regarding decision-making, such as form, timing, and type of meetings (open, closed) are described and recording of meetings is envisaged, but the principle of confidentiality is explicitly addressed only in one university (LT2). An appeal procedure is allowed in one university as well (LT1).

In addition to this, in the press articles eight malpractices are publicly discussed, among which the prevailing one is (self) plagiarism (18 press articles). The public debate on these malpractices involves diverse stakeholders. Among them are politicians (e.g., parliamentarians, vice-minister of education and science), the ombudsman for academic ethics and procedures, and the policy advisor to the President of the Republic of Lithuania, university administration (e.g. rectors, chairpersons of ethics committees), alleged infringers and other academics. This sense of concern derives from sensitive cases where either additional details related to malpractices are presented (e.g. how a university administration makes progress on handling a particular case), or all public speakers are asked to refrain from comments and interfering with a particular case once an ombudsman for academic ethics and procedures makes a decision. Such moderate debate testifies the spotlight on academic integrity. As an example, a president of the Lithuanian university rectors' conference announced that he will set up a Working Group for Academic Ethics and Integrity to provide uniform thematic guidelines for universities. 


\section{Support}

The selected universities have established ethics committees and reference their regulations. However, one out of three universities made ethics committees' regulations on handling malpractices publicly available - it published two regulations, one relating to legal violations and the second relating to academic integrity breaches (LT1), while others incorporated few procedures (e.g. reporting, handling) into the code of ethics.

Since 2006 all universities use the Lithuanian Academic Electronic Library's developed aggregated open access repository that allows one to compare an uploaded paper with its collections, such as bachelor's and master's theses, doctoral dissertations and their summaries, journals, books, proceedings, working papers and empirical data. Only students upload their papers, usually at the very final stage just before the submission for defence. These rules are described in regulations for studies organising and/or regulations regarding final papers.

\section{Conclusion}

The research findings have revealed several similarities in framing academic integrity in Latvian and Lithuanian public universities. In both countries, a code of ethics serves as a core message on academic integrity and all selected universities make it publicly available. However, the access to these codes of ethics is not always easily traceable. Academic integrity-related provisions are integrated also in a few other university documents. This shows explicitly that academic integrity in academia is significant, but, we assume, not necessarily well managed. Additionally, the selected universities describe a large set of breaches in their regulations; however, a (proper) classification by the level of severity is basically missing. Discussions on academic malpractices in online press articles are limited, mostly considering plagiarism and contract cheating. The procedures for effective management of academic malpractices are mainly established in the selected universities, but they are rarely presented at a sufficient level of detail. In both countries, the universities have minimal organisational (i.e. ethical committee) and technical tools (i.e. text-matching software) for supporting academic integrity policy.

Despite these similarities, the countries differ in their approach to academic integrity. While the Latvian universities follow principally a punitive approach, Lithuanian universities additionally communicate the message on academic integrity from an educative perspective. Then, mainly individual responsibility is addressed in the Latvian university regulations and online press articles, while the Lithuanian university regulations proceed to raise academic integrity-related responsibility to the institutional, education system and social levels. In general, the research findings reaffirm that ethics management usually takes different transition pathways in different countries and regions.

Hence, the findings of the research clearly show that the academic integrity policy of the largest Latvian and Lithuanian public universities cannot fully satisfy the components of an exemplary academic integrity policy. The significant limitation of this study is its focus on online publicly available university documents and press articles. This type of evidence delivers only a limited view of university real-life practice, and impedes the evaluation of some components of exemplary academic integrity policy, such as detail and support, in appropriate volume. 
The importance of the research should not be limited to the countries of Latvia and Lithuania. At national and international levels, it could serve as a starting point for further comparative studies. Learning different stages of academic integrity policy development could be used for mapping European countries to better understand causes of academic integrity policy ineffectiveness, as well helping universities to reshape their current policies and aligning them with their core activities, namely teaching, learning and research. Moreover, the research allows further discussion and refining of methodology for addressing academic integrity policy in online public spaces.

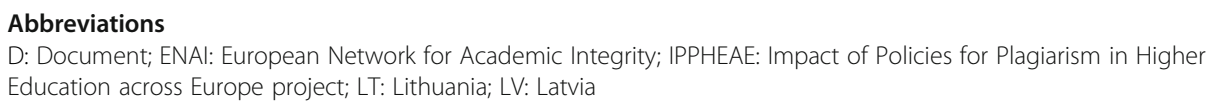

\section{Acknowledgements}

For providing comments on the manuscript, we thank reviewers for their valuable comments for improvement of this paper. Publication costs (APC) for this article have been supported thanks to an educational grant from Studiosity Pty Ltd. The article was independently prepared by the authors and has undergone peer review in accordance with the journal's standard policies and processes. Studiosity Pty Ltd. had no input into the topics covered or the article itself.

\section{Authors' contributions}

AAN is Associate Professor of Information Technology at Riga Technical University. She analysed the literature, designed an empirical research methodologically, analysed empirical data and wrote the manuscript. LT is Researcher of University Social Responsibility and Ethics Management at Vilnius University. She analysed the literature, designed an empirical research methodologically, collected and analysed empirical data and wrote the manuscript. TO is Researcher at Riga Technical University. She collected and analysed empirical data and wrote the manuscript. All authors read and approved the final manuscript.

\section{Competing interests}

The authors declare that they have no competing interests.

\section{Publisher's Note}

Springer Nature remains neutral with regard to jurisdictional claims in published maps and institutional affiliations.

\section{Author details}

${ }^{1}$ Riga Technical University, Daugavgrivas street 2-545, Riga LV-1048, Latvia. ${ }^{2}$ Vilnius University, Muitinės g. 8, LT-44280 Kaunas, Lithuania. ${ }^{3}$ Riga Technical University, Kalku street 1-208, Riga LV-1658, Latvia.

Received: 19 June 2018 Accepted: 19 September 2018

Published online: 12 October 2018

\section{References}

Albert S, Whetten D (1985) Organizational identity. In: Cummings LL, Staw BM (eds) Research in organizational behaviour, vol 7. JAl Press, Greenwich, CT, pp 263-295

Atkinson P, Coffey A (2011) Analysing documentary realities. In: Silverman D (ed) Qualitative research. Sage Publications Ltd, London, pp 77-92

Bieliauskaite J (2014) On the way to professionalism - the promotion of law students' academic integrity. Proc - Soc Beh Sci 116:4229-4234

Bretag T, Mahmud S, Wallace M, Walker R, James C, Green M et al (2011) Core elements of exemplary academic integrity policy in Australian higher education. Int J Edu Int 7(2):3-12

Bridges D (1998) Research for sale: moral market or moral maze? Brit Edu Res J 24(5):593-608

Driscoll D-M, Hoffman WM (1999) Gaining the ethical edge: procedures for delivering values-driven management. Long Range Plan 32(2):179-189

Echenique EG (2014) An integrative review of literature on learners in the digital era. Studia paedagogica 19(4):161-184

Francis R, Armstrong A (2003) Ethics as a risk management strategy: the Australian experience. J Bus Ethics 45(4):375-385

Gemius Baltic (2018) Vasario mènesio svetainiu TOP25 pagal realius vartotojus [TOP25 sites by the number of real users in February] http://www.gemius.lt/visos-naujienos/id-2017-m-pradzia-augino-svetainiu-populiaruma.html. Accessed 20 Mar 2018

Gemius Latvia (2017) Top 10 apmeklētākie ziṇu portāli Latvijā [Top 10 most visited news portals in Latvia] http://www. gemius.lv/agenturas-zinas/top-10-apmekletakie-zinu-portali-latvija.html. Accessed 14 Feb 2018

George A (2009) Quantitative and qualitative approaches to content analysis. In: Krippendorff K, Bock MA (eds) The content analysis reader. Sage Publications, Los Angeles, London, New Delhi, Singapore, pp 144-155

Grady M (1998) Qualitative and action research: a practitioner handbook. Phi Delta Kappa Educational Foundation, Bloomington Hancock B, Ockleford E, Windridge K (2009) An introduction to qualitative research. The NIHR RDS EM/YH

Izglïtības un zinātnes ministrija (2017) Pārskats par Latvijas augstāko izglītību 2017.gadā: Galvenie statistikas dati [Overview of Latvian Higher Education in 2017: Key statistical data]. http://wwwizmgovlv/images/izglitiba_augst/Parskats-par-Latvijasaugstako-izglitibu-2017gadapdf. Accessed 22 Feb 2018

Jones C, Shao B (2011) The net generation and digital natives: implications for higher education. Higher Education Academy, York 
Kaptein M (1998) Ethics management. In: Kaptein M (ed) Ethics management: auditing and developing the ethical content of organizations. Springer, Dordrecht, pp 35-49

Kolb KH, Longest KC, Singer AJ (2015) Choosing not to cheat: a framework to assess students' rationales for abiding by academic integrity policies. Int J for the Scholarship of Teaching and Learning 9(1):9

Leja K (2010) A socially responsible university - an attempt to approach the system. Cont Manag Quar 2-3:21-33

Lietuvos statistikos departamentas (2017) Education 2016. https://ospstatgovlt/services-portlet/pub-edition-file?id=26860. Accessed 3 Mar 2018

Löfström E (2016) Role-playing institutional academic integrity policy-making: using researched perspectives to develop pedagogy. Int J Edu Integ 12:5

Pučètaitè R, Lämsa A-M (2008) Advancing organizational trust in a post-socialist context: role of ethics management tools, Ekonomika ir vadyba 13:381-388

Richards D, Saddiqui S, White F, McGuigan N, Homewood J (2016) A theory of change for student-led academic integrity. Qual Hig Edu 22(30):242-259

Stabingis L (2013) Plagiarism policies in Lithuania. IPPHEAE report http://plagiarism.cz/ippheae/. Accessed 3 Mar 2018

Stabingis L (2014). Plagiarism policies in Latvia: executive summary. IPPHEAE report http://plagiarism.cz/ippheae/. Accessed 14 Feb 2018

Tauginienè L (2015) Socialiai atsakingas universitetas [socially Responsible University]. In: Žičkienè S (ed) Socialinè atsakomybe verslo ir viešajame sektoriuje: mokslo studija [Social Responsibility in Private and Public Sectors: Research Study]. Šiauliụ universiteto bibliotekos Leidybos skyrius, Šiauliai, pp 253-274

Tauginienè $L$ (2016) Embedding academic integrity in public universities. J Acad Eth 14(4):327-344

Tauginienè L, Gaižauskaitė I, Glendinning I, Kravjar, J, Ojsteršek M, Ribeiro L, Sivasubramaniam S (2018) Glossary for Academic Integrity. ENAI Report 3G [online]. http://www.academicintegrity.eu/wp/wp-content/uploads/2018/02/GLOSSARY_final. pdf. Accessed 14 Aug 2018

Upleja A (2012) Akadēmiskais godīgums un izpratne par to [Academic integrity and its understanding]. https://lbbjssword presscom/2012/04/27/akademiskais-godigums/. Accessed 23 Jan 2018

Vasiljevienè N (2006) Organizaciju etika: institucinès etikos vadybos sistemos [organizational ethics: institutional ethics management systems]. VU leidykla, Vilnius

Vasiljevienè N, Jakimenko V (2012) Permąstant integralumo vertybę [rethinking value of integrity]. Societal Innovations for Global Growth 1(1):1026-1041

Wieland J (2003) ValuesManagementSystem ${ }^{\mathrm{ZPW}}$ : a new standard for values driven management. In: Wieland J (ed) Standards and audits for ethics management systems: the European perspective. Springer, Berlin, pp 3-24

Winter RP, O'Donohue W (2012) Academic identity tensions in the public university: which values really matter? J High Educ Policy Manag 34(6):565-573

Winters Spain J, Robles MM (2011) Academic integrity policy: the journey. Bus Comm Quar 74(2):151-159

Ready to submit your research? Choose BMC and benefit from:

- fast, convenient online submission

- thorough peer review by experienced researchers in your field

- rapid publication on acceptance

- support for research data, including large and complex data types

- gold Open Access which fosters wider collaboration and increased citations

- maximum visibility for your research: over $100 \mathrm{M}$ website views per year

At $\mathrm{BMC}$, research is always in progress.

Learn more biomedcentral.com/submissions 